\title{
Diverse Human Resource and Organizational Productivity: Towards an Analytical Framework
}

\author{
Ameen Alharbi \\ Assistant Professor at the CBA, College of Business Administration, \\ University of Business and Technology, Jeddah \\ Email: am-am2020@hotmail.com \\ Aminu Mamman \\ University of Manchester \\ Institute for Development Policy and Management, Oxford Road \\ Manchester, M13 9GH, United Kingdom \\ Email: aminu.mamman@manchester.ac.uk
}

Doi:10.5296/ijhrs.v5i4.8638 URL: http://dx.doi.org/10.5296/ijhrs.v5i4.8638

\begin{abstract}
Experts generally agree that workforce diversity can produce positive outcome such as novel and diverse ideas. However, research evidence indicates that workforce diversity can lead to undesirable outcomes as well. For example, research indicates that performance of a sample of managers was lower when assigned to a diverse group. Another study found that, while performance of some women is higher in a mix-sex group than in same-sex group, men's performance is higher in an all-male group. The main purpose of this paper is to put forward an analytical framework that can help to explain why diverse employees do not always produce desirable outcomes. Using Social Exchange, Organizational Citizenship Behavior, and Organizational Commitment theories the paper explains why and how diverse employees respond to the treatment they receive from the organization and its members. The framework yields research and practical implications for managing diversity.
\end{abstract}

Keywords: Human Resource Management, Managing Diversity, Organizational Productivity 


\section{Introduction}

Many researchers and practitioners agree that workforce diversity can produce positive outcomes (e.g. Copeland, 1988a,b; Cox, 1991; 1993; Cox and Blake, 1991; Fitzsimmons and Eyring, 1993; Heery, 1994; Jackson, LaFasto, Schultz, \& Kelley. 1992; Maruyama, 1994; McNerney, 1994a,b; Powell, 1998; Stephenson and Krebs, 1993 Thomas, 1990; 1993; Tsui, Egan, \& O'Reilly. 1992; Tung, 1993). The case for diversity has been made for many reasons, not least for its strategic contribution to organizational competitiveness (Cox, 1991; Cox and Blake, 1991; Powell, 1998; Maruyama, 1994). The strategic importance of diversity has been interpreted in terms of specific and unique qualities which certain categories of employees bring to the organization. Typical of such inputs are novel ideas, creativity, cultural skills, language skills, working styles, strong work ethic, taking on extra responsibilities by virtue of diverse employees' "unique" backgrounds. Arguably, these inputs fall into beyond the call of duty. This is because employees are not rewarded for or trained in order to exhibit such behavior (Organ, 1988). This is what widely known as extra-role behaviour, and Organizational Citizenship Behaviour (OCB) is the most popular category. Indeed Van Dyne, Graham \& Dienesch (1994) argued that extra-role behavior is underlined by the importance of organizational innovation, flexibility, productivity and responsiveness to changing external conditions. And extra-role behavior has been argued to be critical for organisational effectiveness because managers cannot foresee all the contingencies that may desire employees to perform (Morrison \& Phelps, 1999). Thus, the benefits that will accrue from using diverse workforce can be adequately captured by the concept of extra-role behaviour.

In spite of this optimism, the relationship between workforce diversity and positive outcomes is not always as straight forward as it seems (Richard, 2000). For example, research indicates that performance of a sample of managers was lower when assigned to a group with diverse backgrounds (Earley, 1993). Similarly, evidence suggests, while performance of some women is higher in a mix-sex group than in same-sex group, men's performance is higher in an all-male group (Wood, 1987). Another study found that men in a diverse workgroup have lower job satisfaction and commitment than their counterparts in a homogenous workgroup (Tsui, Egan, \& O'Reilly, 1992). And there is evidence which associates workforce heterogeneity with management turnover (Wiersema and Bird, 1993), health problems, and lower productivity (James, Lovato, \& Khoo, 1994; Kasschau, 1977). In a study of the impact of diversity on organizational performance, Richard (2000: 171) reported that the positive impact of racial diversity on firm performance depends on the context. The author found that in the absence of consideration of context, a negative relationship between cultural diversity and firm outcomes may emerge. The author argued that diversity can increase coordination cost, therefore firms should be particularly aware of the implications of a clash between diversity and organizational context such as downsizing.

Moreover, demographic similarity can engender group solidarity and greater integration and interpersonal communication (Back, 1959; Lott and Lott, 1961). In fact cross-cultural studies revealed that similarity leads to reduction in uncertainty and anxiety, and generates reciprocal feelings (Bobad and Wallbott, 1986; Brewer and Campbell, 1976) which are essential for job satisfaction and employee productivity. The greater the difference between 
two cultures the more difficult it would be for people to interact effectively with one another (Black, Mendenhall \& Oddu. 1991), and empirical evidence generally confirmed this view (Babiker, Cox \& Miller,

1980; Gudykunst, 1985). Also, research evidence revealed that cultural similarity generates reciprocal feelings and that people who are similar culturally tend to like each other (Brewer and Campbell, 1976), whereas differences in values and beliefs can generate discrimination against out-groups (Fernandez, 1981; Greenberg, Pyszczynski \& Solomon. 1986; Katz and Hass, 1988).

We believe the major limitations in research on diversity are two fold: Firstly, the is absence of analytical framework that explains the conditions under which diversity can deliver desirable outcomes. Although theories explaining diverse employees behaviour abound, they are not adequately integrated with HRM and organisational practices. Secondly, there is almost total absence of conceptual framework that captures the benefits of diversity. Again, empirical evidences on the cost and benefits of diversity abound. Yet, these evidences are not aggregated in a way that provides a conceptual categorisation that can be subjected to theorisation and further analysis. By using the concept of extra-role behaviour, we believe this limitation can be addressed.

\section{Analytical Framework}

In the light of the conflicting outcomes of diversity and the growing need for theoretical development on the topic (see Brickson, 2000), this paper puts forward an analytical framework that can improve our understanding of the issue. The key question this paper addresses is: Given that extra-role behaviour is one of the main desirable outcomes of a diverse workforce, what would influence a diverse employee to engaged in extra-role behaviour? To achieve this objective, a multidisciplinary approach will be adopted. The literature on social exchange theory and Organisational Citizenship Behaviour (OCB) will guide our quest for answer to the question of why diversity does not always achieve desired outcomes. The two theories will help to explain why and how diverse employees would respond to the treatment they receive from their organization and its members.

Central to our framework is the idea that : (a) extra-role behaviour (OCB) is the best way to capture the benefits of diverse workforce; (b) OCB of a diverse employee is first and foremost influenced by cognitive process. This means that the employee will gather and process information regarding his/her experience with the organization and its dominant members before deciding whether to engage in extra-role behaviour. This process takes place over medium to long term period. In the short period, the will not be in position to make informed decision on whether or not to engage in OCB.

Although organizational practice can influence employees' commitment and OCB, current theories do not adequately explain the relationship between diverse employees' affective commitment and their OCB. We believe social exchange theory and the idea of integration, provide building blocks for developing a framework that can help to explain how organisational practices and dominant groups' attitudes and behaviour towards diverse 
employees relate to commitment and OCB. We believe the framework will shed more light on why diverse employees would not engage in extra-role behaviour. Similarly, it offers a partial explanation to why diverse workforce does not always lead to desirable outcomes. This is because personal and organisational factors can hinder diverse employees ie integration and commitment, which are essential for desirable outcomes such as OCB.

Figure 1 illustrates the factors that can influence diverse employees ${ }^{\text {ee }}$ extra-role behavior in a work setting. We propose that diverse employees' level of integration in the workplace will depend on organizational factors and employee factors. Integration is defined in terms of diverse employees' perception and feelings of fairness, belonging, inclusion, respected and freedom to behave normally. Using social exchange theory, we argue that diverse employees who have positive perception and feeling of integration would reciprocate by moral and affective commitment to their organization. In fact Hicks-Clarke and Iles (2000) found that perception of organisational justice strongly predicts organizational commitment. And research by Singh (1998) suggests that when employees feel that they are treated unfairly, their foundation of future psychological contract change. Such employees are more likely to be concerned primarily with their personal wellbeing than organizational objectives. And it has been argued that committed employees work harder and better because organizational commitment is a measure of their psychological state, which is important in determining their subsequent behaviour and responses at work (Etzioni, 1964; Meyer, et. al., 1989; Singh, 1998). Therefore, in line with research evidences (Morrison, 1994; Schwartz \& Tessler, 1992; Tsui et al. 1997), we posit that diverse employees' moral and affective commitment will influence their organizational citizenship behaviour (OCB).

\section{Background}

\section{Social Exchange Theory}

According to Blau (1964) social exchange is a relationship that is based on unspecified future obligations. And such exchange does not occur on a quid pro quo basis. Holmes (1981) also argued that social exchange entails trust between parties in the exchange believing that each will discharge their obligations in the longrun. Blau (1964) posit that trust, commitment, and loyalty are the bedrock of social exchange without which the exchange will not take place. Other writers who subscribe to many versions of exchange theory include Goodman (1974), Adams (1963), Homans (1974) and Jacques (1961). When a diverse employee joins an organization, explicit and implicit contracts are involved. The former relates to specific exchange such as hours of work for specific amount of money i.e. economic exchange (Blau, 1964). The latter is a social exchange (Blau, 1964) based on unspecified obligation such as extra-role behaviour in return for organizational support, recognition and protection (Rousseau, 1989). As Rousseau and Parks (1993) pointed out, relational psychological contract entails open ended and long-term obligations based on exchange of socio-emotional elements such as loyalty and support. Although the relationship is not based on quid pro quo, failure to meet the obligation would provoke reciprocation. Indeed, many researchers have indicated that when employees feel that they are unfairly treated by the organization, they exhibit lower organizational commitment, decreased work effort and higher turnover 
(Brockner, Tyler, \& Cooper-Schneider, 1992; Sign, 1998). Therefore, systemic discrimination and failure to support and protect diverse employees when discriminated or harassed would lead to withdrawal from OCB.

\section{Description of OCB}

According to Organ (1988), OCB is a constructive behaviour that is not rewarded explicitly and they fall outside the employee's job description. Also employees do not receive training in order to exhibit OCB. OCB is argued to be critical to organizational functioning because organizations can no longer rely on blueprints of prescribed behaviour (Katz, 1964). Organ (1988) categorised OCB into Altruism, Compliance, Sportsmanship, Courtesy, and Civic virtue. Altruism refers to behaviours directed at helping coworkers. Why would a diverse employee who is harassed and discriminated against voluntarily help others? In fact, because of the employee's background, he/she might not have the opportunity to offer help. When such help is offered it might not be accepted or valued by some members of the organization. In fact research by Tsui et. al. (1992) and Greenhaus et. al. (1990) revealed that because of their negative experiences in organizational setting, minority employees tend to be less psychologically committed and less satisfied with their career. Thus, diverse employees might not engage in OCB if organizations fail to provide the environment for such behavior to occur. Hence the relevance of organizational factor in influencing diverse employees' integration.

Compliance refers to employee's conscientiousness beyond enforceable expected standards. Van Dyne et al. (1994) used the term obedience to refer to similar behaviour i.e. adherence to organisational rules and policies. While employees do not always have much option but to comply with organizational rules, there are few situations when they can have the opportunity to choose between obedience and disobedience. When such opportunity arises, their level of affective and moral commitment would influence their choice of action. I posit that the higher their level of commitment the more likely that they will chose to obey organizational rules and vice-versa. As depicted in the framework, commitment is influenced by diverse employee's level of integration.

Sportsmanship refers to tolerance of inconveniences from the job (Organ, 1988). Many diverse employees as well as their counterparts in the dominant group are subjected to poor working conditions. The level of their affective and moral commitment to the organization would influence their tolerance of such inconveniences at work. In line with social exchange theory, high level of integration will be reciprocated by affective and moral commitment, which would lead to tolerance of inconvenience in the workplace. If the inconvenience is in the form of prejudice or negative stereotype, the diverse employee would withhold exhibition of OCB or withdraw his/her service to the organization altogether (Elsass \& Graves, 1997). Indeed Wiersema and Bird (1993) pointed out that the focus on shared group beliefs and the value attached to group affiliation and cooperation may encourage individual members to tolerate high levels of personal discomfort or alienation. 
Courtesy means consulting others before making decisions that affects them (Organ, 1988). Like altruism, diverse employees"e willingness to engage in courtesy would depend on the opportunity to do so. It would also depend on whether their effort to consult others is valued by the organization and its members. It can be argued that, being different, a diverse employee would have an added difficulty to gain the opportunity to consult and his/her consultation to be valued by people who believe he/she does not deserve the opportunity in the first place. Therefore, to ensure this dimension of OCB to occur, the employee has to be integrated and committed to the organization.

And finally, Civic Virtue refers to the active participation in organization's affairs (Organ, 1988). Van Dyne et al. (1994) used Social Participation to refer to the same concept. Active participation in organizational activities would depend on diverse employees' affective and moral commitment, which is derived from their level of integration in the organization. It is difficult to imagine a situation in which an alienated employee is actively participating in organizational affairs. In fact, Elsass and Graves (1997) argued that diverse employees might experience low quality social exchange relationships leading to exclusion pattern of exchanges. The authors cited research by Cox (1993) and Heilman (1983) which indicate that some diverse employees contribute to group tasks at a lower level, make fewer influence attempts, are less likely to be selected as leaders, and are less committed to group outcomes.

\section{The Relevance of OCB to Diversity}

For the purpose of this paper, OCB is the preferred mode of behaviour not only because organizations are increasingly focusing on proactive employee behaviour (Organ, 1988), but also because there is a high possibility that diverse employees would fail to engage in OCB. Given the added complexity of diversity, the requirements for, and the difficulties in eliciting OCB will be higher in a diverse workforce than in a homogenous one. And there would be high potential for alienation and exclusion in a diverse workforce (Cox, 1993; Heilman, 1983) which can hinder employees to engage in OCB. For example, Elsass and Graves (1997: 955) pointed out "racioethnic and gender differences in access to organizational resources, including information or political contacts, may lead to the exclusion pattern. Majority group members belong to informal networks that provide information or other resources, but women and people of color typically do not". Another reason for the relevance of OCB is the difficulty (or impossibility) of incorporating all the potential benefits of diverse backgrounds into a contract of employment and job description. For example, an organization cannot effectively incorporate advocacy (Van Dyne et al., 1994) and sportsmanship (Organ, 1988) into a job description. Thus, OCB can be measure of the degree of success of social exchange between the diverse employee and the organization. I believe in-role behaviour (represented by explicit job description) will be inadequate to capture and assess the response of diverse employees who felt mistreated, discriminated and alienated by the organization and its members. This is because, due to lack of option, especially during high unemployment, diverse employees would continue to offer their service to the organization anyway, but concentrating on in-role behavior only. However, when diverse employees are treated fairly, they would reciprocate by engaging in OCB (Konovsky \& Pugh, 1994; Van Dyne et al. 1994). 
Explaining the theoretical basis for the relationship between OCB and distributive justice, Organ $(1988$; 1990) suggested that employees would respond to inequity and unfairness by decreasing the exhibition of OCB. In fact many researchers suggested that employee perception of procedural justice would influence OCB (Fahr, Podsakoff \& Organ, 1990; Moorman, 1991; Niehoff \& Moorman, 1993). And researchers have demonstrated empirically, that when employees feel they are treated well by their organization, they reciprocate by helping the organization and its members (Van Dyne et al. 1994; Van Dyne \& Ang, 1998). And empirical investigation by

Sanchez and Brock (1996) found a strong correlation between perceived discrimination among Hispanic employees and their organisational commitment.

\section{ORGANIZATIONAL FACTOR}

Many organizational factors can influence diverse employees ${ }^{e e} \mathrm{OCB}$ in the workplace. In this section we highlight the following:

\section{Breadth and Depth of Workforce Diversity}

Demographic characteristics of employees can vary across organizational structure. For example, irrespective of sector or country, it is widely acknowledged that men dominate top management positions in most organizations (Adler \& Izraeli, 1994). The terms breadth and depth is used to describe the degree of diversity across the organization. For example, Breadth of diversity refers to the diversity of the workforce across the horizontal structure (e.g. units, departments, functions) of the organization, whereas Depth of diversity refers to the diversity of the workforce across the hierarchy of the organization. Both categories of diversity can influence diverse employees' level of integration. For example, researchers have argued that under-representation of women in organization is associated with increased performance pressure, isolation and stereotyped role (Ely, 1995; Kanter, 1977; Wharton, 1992). And researchers on organisational demography posit that over-representation of men in high-status positions can reinforce the devaluation of women's jobs (Pfeffer, 1983; Ridgeway, 1988). Degree of workforce diversity is relevant because it can determine the extent of social support for the diverse employee. And social support often moderates the effects of work stressors (Beehr et al. 1990; George et al. 1993; Kiremyers \& Dougherty, 1988). Social support is important because minorities face significant difficulties in gaining social and instrumental support in the work setting (Thomas \& Alderfer, 1989) and that leads to failure in career advancement (Fernandez, 1991; Morrison \& Von Glinow, 1990).

Evidence suggests that low level of diversity (tokenism) can produce negative consequences to employee adjustment in a work setting (Blau, 1977; Kanter, 1977; 1990; Morrison et al. 1987; Pettigrew and Martin, 1987). Conversely, high level of heterogeneity, especially across the organizational hierarchy will provide role models, which can be important for employees' adjustment (Horgan, 1989; Van Velsor and Hughes, 1990). This is because in a cosmopolitan situation strangers are more likely to adjust easily because the majority of the population will be used to diversity (Gudykunst and Kim 1984). Therefore, it can be argued that the more diverse the workforce, the more likely that its members will be familiar with, and tolerant of 
differences between people. Researchers have also found that current composition of the workforce can affect future levels of minority segregation (Perry et al. 1994). Thus, low level of diversity (tokenism) can produce negative outcomes (alienation and pressure), while "appropriate" level of diversity would produce positive outcomes (inclusion and social networks) (Blau, 1977; Kanter, 1977).

Proposition: Other things being equal, the higher the depth and breadth of diversity in the organization the higher the level of diverse employee's integration would be.

\section{Organizational and Job Design}

That organizational structure and job design can influence employee integration has already been acknowledged (Pettigrew and Martin, 1987). For example, job design and dominant method of communication in the organization can determine the extent and style of how diverse employees interact with the dominant group. This can influence diverse employees' perception of integration, social support and job satisfaction. Indeed Stone \& Colella (1996:373) argued “....systems that value standardisation and impersonalization (e.g. bureaucratic system) may place disabled persons at a disadvantage relative to others because disabled individuals may be unable to comply with inflexible rules and procedures. Therefore, we predict that disabled persons will experience more obstacles to job performance and greater treatment related problems in bureaucratic organizations than in those organizations that value flexibility and personalisation".

Indeed experts have already encouraged organizations to design their jobs to ensure total integration of the workforce (Pettigrew and Martin, 1987). Perhaps the most recent and significant theoretical effort to establish a relationship between organizational structure and diversity was made by Shelley Brickson. Brickson (2000) argued that an atomised organisational structure in which individual's separation from others is more significant than their integration with others, organizational members will have to rely more and more on themselves than on network relationship or others for resources or information. And "When organizational structure is such that integration between groups is weaker than boundaries separating them, categorization is encouraged and individuals are apt to view themselves primarily in terms of their group membership" (Brickson, 2000: 90). Brickson (2000: 92) is of the view that demographic distinctions may be more consequential in organizations that activate a collective identity orientation. And that relational identity orientation will be encouraged by an organizational structure that emphasize dense and integrated networks of relationships. And dense and integrated networks will reduce employees' tendency to categorize themselves into groups. In other words, such structure will make it less likely that individuals see themselves as members of specific groups and that would increase the extent to which employees view themselves as relationship partners.

Proposition: Diverse employees' level of integration will depend on job design and organizational structure. Other things being equal, the less rigid and more integrated is the is the structure, the more and quicker diverse employees would integrate. 


\section{Organizational Culture}

Organisational culture represents, among other things, the values the organization holds regarding fairness and equity. When such values conflicts with employeees values, then the employee is less likely to engage in extra-role behaviour. Indeed Deckop (1999: 422) argues, "when the values of individuals are tightly aligned with those of the organization, the employment exchange is social rather than economic, and OCB may not be perceived as a cost". In an article devoted to the development of a model of factors affecting the treatment of disabled people in organizations, Stone \& Colella (1996: 373) posit that: "Organizational norms and values may influence the experiences of disabled individuals in organizations. The primary reason for this is that an organization's norms and values identify the types of behaviors that are appropriate and provide moral justification for organizational policies and practices. For example values associated with equity, standardization, impersonality, and separation of job and job holder define the policies and practices in a bureaucratic organization". Mayer and Schoorman (1992) posit that belief in and acceptance of organisational values will lead to willingness to exert considerable effort on the part of the organization. In fact Deckop et al. (1999) found negative impact of pay for performance on OCB for employees low in value alignment with their organization. In a study of organisational climate for diversity, Hicks-Clarke \& Iles (2000: 341) reported that a positive climate for diversity (as indicated by perceptions of policy support, organisational justice, support for diversity and recognition of the need for diversity) is strongly related to organizational commitment, satisfaction with manager, career satisfaction, and career future satisfaction.

Proposition: Diverse employees' level of integration will depend on organizational culture.

\section{Organizational Policy and Practice}

A number of researchers have explored the impact of HRM policy and practices on employee behaviour such as productivity and turnover (Jones \& Wright, 1992; Kleiner, 1990). Specific working practices such as comprehensive employee recruitment and selection, incentive compensation and performance management systems, extensive employee involvement and training have been argued to improve employees ${ }^{e e}$ knowledge, skills and abilities which will subsequently increase their level of motivation and willingness to stay (Huselid, 1995; Jones \& Wright, 1992). The relevance of organisational policy and practice vis-à-vis workforce diversity is anchored in theoretical and empirical evidences, which suggest that organisational policy, and practice can influence employee attitudes and behavior ( Black and Mendenhall, 1990; Black et al. 1991; Cox, 1991; Harris, 1994; Heery, 1994; Jackson, et al., 1992; Jenner, 1994; Konrad \& Linnehan, 1994; McNerney, 1994a; Perry, Davis-Blake \& Kulik, 1994; Smith, 1994; Stephenson \& Krebs, 1993; Tung, 1993). For example, organisational policy and practice can either support or hinder employee integration and commitment. Policies and practices can be support mechanisms which can provide diverse employees with the condition to behave beyond contract. Inadequacy or total absence of such support mechanism would generate perception and feeling of alienation and exclusion. For example, in a comparative study of expatriates, repatriates and domestic workers, 


\section{Macrothink}

International Journal of Human Resource Studies

ISSN 2162-3058

2015, Vol. 5, No. 4

Feldman and Holly (1993) found a significant positive relationship between mentoring and employee satisfaction with supervisor, job security, psychological well-being and ability to work with diverse workforce. Therefore such policies should relate positively with employee integration. In fact social exchange theorists argued that perceived organisational support could lead to extra-role behaviour. This is because organisational support is an indication of how the organization values the employee (Eisenberger et al. 1990). Using social exchange theories, Eisenberger et al. (1986) posit that perceived organisational support underlie employees ${ }^{\text {ee }}$ inference concerning their organization's commitment to them, which in turn contribute to employeese commitment to their organization. Wayne et al. (1997) maintained that: "High level of perceived organizational support create feelings of obligation, whereby employees not only feel that they ought to be committed to their employers, but also feel an obligation to return the employer's commitment by engaging in behaviors that support organizational goals. That is employees seek a balance in their exchange relationships with organizations by having their attitudes and behaviors commensurate with the degree of employer commitment to them as individuals"

Eisenberger et al. (1986) and Wayne et al. (1992) found strong relationship between commitment, innovation and OCB. Moorman, et al. (1998) also reported a relationship between procedural justice and perceived organizational support, and between perceived organizational support and OCB. These findings offer support for the framework advanced in this paper which suggests a relationship between attitude (commitment) and behavior (OCB). Tsui et al. (1997) hypothesized that OCB will be higher under the mutual investment employee-organization relationships than under other types of relationships. The authors argued that in a mutual employment relationship "The inducement an employer offers go beyond short-term monetary rewards. They include an extended consideration of an employee's well being as well as an investment in the employee's career within the firm. In exchange, the employee's obligations and contributions include working on the job assignments that fall outside of prior agreements or expertise, assisting junior colleagues, accepting job transfers when requested by the employer to do so, and, in general being willing to consider the unit's or organization's interests as important as core job duties" ( $p$. 1092). Reporting support to their hypothesis, Tsui et al. (1997: 1114) maintain that "The overall pattern of our result provides general support for what we have termed the mutual investment approach, where open-ended inducements provided by employers are balanced by open-ended contributions from employees. Employees under mutual investment employee-organization relationships generally performed better, as rated by both supervisors and peers, and had more favorable attitudes than employees managed under any of the other three employee-organization-relationships approaches". Tsui et al. (1997: 1114) also reported that their results indicate that, "relative to employees in jobs characterized by any of the other three employee-organization relationships approaches, employees in jobs characterized by mutual investment demonstrated the highest levels of core task performance and OCB. The mutual investment approach involving a combination of social and economic exchange, seems to yield the most returns in terms of productivity at the job level as well as the firm level..." 
Proposition: Diverse employees' level of integration will depend on the existence and effectiveness of diversity related strategy, policies and practice.

\section{Internal Contingencies}

It has been argued that large and unionised firms tend to provide regularised and well exercised forms for resolving workplace problems, while small and non-unionised firms tend to rely on particularistic and arbitrary procedures to resolve workplace disputes (Gwartney-Gibbs and Lach, 1994; Westin and Felieu, 1988). Some researchers (Pfeffer, 1983) have acknowledged the influence of unions on organizations and its members. Level of trade union support can help reduce discrimination and harassment which can influence diverse employee adaptation in the organization. For example, in a study of gender-based wage and promotion discrimination in Israel, Bamberger, Admati-Dvir and Harel (1995: 1757) reported, "On the whole, our findings suggest that female employees in unionised firms may experience no less gender-based wage and promotion discrimination than their colleagues in similar, non-union firms.... However, we also found that the impact of promotion discrimination on earnings was less severe in the unionised firm than in the nonunion firm".

Another dimension of organizational contingencies pertain to litigation associated with discrimination and sexual harassment. Researchers have found that, organizations, which are sued and/or monitored, are more likely to pay particular attention to diversity issues (Baron et al. 1991; Konrad, and Linnehan, 1995). It can be argued therefore that the degree of employee integration would be influenced by the experience of the organization with litigation and/or being monitored. In other words, institutional factor can play a major role in influencing organisational policy and practices vis-à-vis diversity which will indirectly affect employee integration.

Ownership of the organization could also impact on employee level of integration and commitment and subsequent behavior. Arguably, given that government institutions are more likely than private firms to be under strict regulation on equal opportunity, they are more likely to address employees' concerns regarding adjustment in the workplace. The above argument is in line with both institutional and resource dependence theories of the firm. Proponents of these theories argue that organizations would adopt systems and structure of management in order to gain legitimacy or resources necessary for survival (DiMaggio \& Powell, 1983; Meyer and Rowan, 1977; Pfeffer\& Salancik, 1978; Pfeffer\& Blake, 1987; Zucker, 1987).

Proposition: Organizational contingencies such as ownership, experience with diversity issues, and unionization can influence employee level of integration.

\section{EMPLOYEE FACTOR}

At the end of the day, OCB of a diverse employee is not going to be determined by organizational and contingency factors alone. For example, it can be argued that regardless of the condition some employees found themselves in, they are more likely than other employees to engage in OCB. Therefore, there are certain attributes possessed by some diverse employees that contribute to their integration which ultimately lead to OCB. The 
attributes can be categorised into psychological (Self-concept; Attitudes, Personality \& Cognition) and non-psychological (Behaviour; Experience \& Demographic Background).

\section{Psychological Attributes}

The notion of self-concept is important in understanding diverse employeese level of integration in the organisational setting. This is because, the extent to which dominant group's attitudes and behaviour can affect a diverse employee's integration would be influenced by his/her self-concept. Self-concept (the meaning people attach to their own backgrounds) is an interactive structure that moderates how people behave and feel in a social context (Markus and Wurf, 1987; Schenkler, 1985). A person's self concept may be composed of a variety of identities which evolves from membership in different social groups such as race, gender or age (Breakwell, 1986; Stryker and Serpe, 1982). People's self-conception usually influences their attitude and behaviour during social interaction. Dutton, et al. (1994) argue that a person's well-being and behaviour are affected both by the attributes they ascribe to themselves and by those they believe others infer about them from their membership of a particular social group. Citing Cialdini et al. (1976), Dutton et al. (1994) made the point that when people believe that outsiders see their social group in a positive light, they "bask in the reflective glory" of the group and this can lead to desirable outcomes such as positive mental and psychological state. However, when people believe that outsiders see their social group in a negative light, they experience negative personal outcomes such as depression and stress which could lead to other negative outcomes (Dutton et al. 1994; Hirschaman, 1970; Kahn, 1990).

Proposition: Because people want to maintain the continuity of their self-concept overtime and across environments (Steele, 1988), when faced with negative attitudes such as stereotype and prejudice, diverse employees' mental and psychological state can be negatively affected, and this can lead to lower integration.

Given that diverse employees are operating in an environment and dealing with people who are not familiar to them, they will experience situations which can be unpleasant especially if the organisation does not have effective diversity policy and practice. Therefore, their ability (attitude \& personality) to deal with such unpleasant situation will influence their level of integration in the organisation. In fact researchers argue that in a foreign setting, the acquisition and demonstration of appropriate social skills should be complemented with the right attitude and personality (Brislin, 1981; Ruben, 1976). Some of the personality and attitudinal factors are: flexibility, self-confidence, self-efficacy, openness, motivation, orientation to knowledge, cultural empathy, openness to information, and optimism. These attitudes and personality factors can help the diverse employee to cope and deal with negative stereotypes for example.

Proposition: The level of diverse employees' integration in the organisational setting will be influenced by their personality and attitudes.

We have agued in our framework that a diverse employee's OCB starts with cognitive process. This is because, it is widely agreed that the acquisition and use of knowledge can 
influence the process and outcome of social interaction (Detweiler, 1980; Gertsen, 1990; Gudykunst and Kim, 1984; Mendenhall and Oddou 1986; Oddou and Mendenhall, 1984; Singer 1987; Triandis, 1976; 1977). Therefore employees need to acquire knowledge relevant to effective interaction in a diverse workforce (Detweiler, 1975; 1978; 1980). In other words, employees who have accurate knowledge of their experiences in the organisation are more likely to exhibit "appropriate" behavior. The relevant and accurate knowledge should include that of own's socio-psychological background as well as the dominant group's (Gudykunst and Kim 1984; Kim, 1977; Segall et al. 1990; Triandis et al. 1993). Appreciation of these differences is necessary for accurately interpreting others attitudes and behaviour.

Proposition: Employees who have adequate and accurate knowledge of their own and the dominant group's socio-psychological backgrounds are more likely to adapt and integrate quickly in the workplace.

\section{Non-Psychological Attributes}

Why and how people behave is one of the key determinants of the outcome of any social interaction. Depending on the dominant group's knowledge and attitudes, a diverse employee's behaviour during interaction in the workplace can be interpreted negatively. In fact experts on expatriate management have underscored the significance of demonstrating "socially appropriate" behaviour when interacting with people from a diverse background (Brien and David 1971; Hammer, et al. 1978; Mendenhall and Oddou, 1986; Ruben 1976). Some of the behavioural dimensions that can enhance integration include: ability to develop and maintain satisfying interpersonal relationships with "strangers", accurately understand their feelings, effectively work with them, empathise and effectively deal with their different social customs; ability to enter into meaningful dialogue, initiate interaction and deal with misunderstandings and interpersonal conflict and different communication styles (e.g. Gudykunst and Hammer, 1984; Hammer 1987; Hammer et al. 1978). Evidence from expatriate adjustment indicates that technical ability leads to higher adjustment (Bardo and Bardo, 1980; Hawes and Kealey, 1981; Hays, 1971; Tung, 1981). Thus, it is reasonable to argue that diverse employee's behaviour can enhance his/her social attractiveness leading to higher integration.

Proposition: Diverse employees who are able to behave appropriately are less likely to experience intra and interpersonal conflict, and lower level of conflict will lead to higher integration.

Some of the psychological attributes described above can be acquired with experience. Thus, a diverse employee's attitude and behaviour can be influenced by prior experience. This is because evidence have shown that people who have had prior experience with foreign settings are more likely to find it easier to adjust to unfamiliar environments than those who have not (e.g. Black et al. 1991; Furnham and Bochner, 1986; Klineberg, 1981). Similarly, research on cross-cultural interaction indicates that familiarity with host culture can act as a buffer against the effects of perceived discrimination (Mendoza, 1989; Sanchez \& Fernandez, 1993). Thus, it can be argued that a diverse employee's experience (including tenure) with a 
diverse workforce could enhance his/her integration (Adler, 1975; Bardo and Bardo, 1980; Dodd, 1982; Kim, 1977; Torbiorn, 1982).

Proposition: Experience in working in a diverse workforce will lead to better understanding of diversity and lower conflict and integration. In other words, the longer employees stay in the organisation, the more likely they will acquire attitudes, behaviour and knowledge that will enable to integrate.

It is widely acknowledged that adjustment in a new setting is significantly influenced by the culture novelty of the setting (Black et al. 1991; Gullahorn and Gullahorn, 1963; Torbiorn, 1982; Dinges, 1983). The greater the difference between two cultures the more difficult it would be for people to interact effectively with each other (Black et al. 1991), and empirical evidence generally confirms this proposition (Babiker et al. 1980; Gudykunst, 1985). For example, Gudykunst (1985) found that culturally similar people display high attributional confidence and shared network, which in turn reduce uncertainty and anxiety. Values and beliefs that emphasises conformity to group norms are more likely to alienate "others" than values which are less conformist. Indeed Wiersema and Bird (1993: 1001) argue, "groups in collectivist societies are likely to strongly encourage conformity. One consequence of that practice may be greater sensitivity to differences that an outsider might consider trivial".

Markus and Kitayama (1991) argued that the primary unit of consciousness in individualistic society is personal identities. In a collectivist society on the other hand, the primary unit of consciousness and identification is membership of a group. The authors are of the view that primary unit of consciousness "are most significant in regulating behavior and are assumed both by the actor and the observer" (Markus and Kitayama, 1991: 226). Thus, a diverse employee's culture could influence his/her interpretation of and reaction to how he/she is treated by the dominant group. It can be argued that, compared to individualists, collectivists are more likely to be affected by the dominant group's negative attitudes towards their ethnic or racial group for example. This is because, individualists define themselves as autonomous entity independent of groups, whereas collectivists define themselves in relation to others. When a member of their group is criticised, they may find it difficult to isolate themselves from the criticism. Chatman and Barsade (1995) found that collectivists cooperated significantly more under a cooperative rather than uncooperative organizational culture, whereas individualists were less cooperative irrespective of the organizational culture. This is a further indication that culture can influence diverse employees' reaction to the organization and its members.

Proposition: Diverse employee's level of integration will depend on their his/her cultural background.

Given that social network is a resource that can help adjustment and integration in a work setting, a diverse employee's demographic background can influence their level of integration. For example, experts argue that interpersonal similarity enhances ease of communication, improves predictability of behavior and fosters trust and reciprocity (Ibarra, 1995). And Marsden (1988) maintained that minorities have much smaller set of same-race others with whom to have informal interaction (Ibarra, 1995). Even if minorities form relationships 
across race, Thomas (1990) argued that the cross-race relationship tends to be weaker than same race relationships. Thomas also revealed that racial differences were often an obstacle for white mentors in identifying positively with their African American proteges. Others reported that similarity could affect supervisor ,s personal attraction to and identification with subordinates (Tsui and O'Reilly, 1989). And Kanter (1977) in her seminal work on the experience of women managers suggested that demographically different individuals feel least socially integrated in the work setting. Rather than delve into detailed discussion of the negative experience of diverse employees in organization, it is perhaps more useful at this level of analysis to provide theoretical explanation to why and how diverse employees' demographic backgrounds can affect their integration. The relevance of employees ${ }^{\text {ee }}$ demographic backgrounds can be understood primarily from the dominant groups' attitudes towards their demographic backgrounds.

Basically, others' attitudes towards a diverse employee's backgrounds can be explained using the concepts of stereotype, and ethnocentrism. Stereotype is a social process in which people are assigned attributes solely on the basis of their group identity (Tajfel, 1969; Wiseman, et al. 1989). Stereotype can take the form of positive as well as negative attributes, or both (Bizman and Amir, 1982). Because people try to justify the stereotype they hold about others, even to the extent of "inventing differences" (Summer, 1906) and "projecting similarity" (Adler 1991), the stereotypical image of an employee's background held by others can influence attitudes and behaviours during interaction. Thus, integration can be influenced by the nature and extent of stereotype. If co-workers hold a positive stereotype of an employee's demographic background, the outcome of interaction is likely to be positive and vice-versa, and this will affect his/her integration and commitment.

According to Summer (1906), ethnocentrism relates to positive feelings towards one's own group and negative feelings towards others. Others, such as Adler (1991) and Gudykunst and Kim, (1984) view ethnocentrism as a tendency to identify one's "in-group" behaviour, and to evaluate "out-groups" (others) according to that standard. Empirical evidence supports this view. For example, studies have revealed that people generally like their own groups best and perceive them in the most positive light and perceive "out groups" less favourably (Brewer and Campbell, 1976; Marjoribanks and Jordan, 1986). Those who concur with Summer's definition view ethnocentrism as an attitude inspired by negative feelings (Mayer, 1984). Going by the above definitions, other things being equal, employees are likely to receive unfavourable attention if their demographic backgrounds if their behaviour differ markedly from that of the others. However, this should depend, in part, on the level of ethnocentrism, which tends to vary across cultures.

Proposition: The higher the level of ethnocentrism and negative stereotype, the lower would be diverse employees' level of integration.

\section{EMPLOYEE INTEGRATION}

The idea of integration is important when explaining employees' behavior in a diverse setting. This is because the likelihood of employee alienation is higher in a diverse workforce than in a homogenous one. Taft (1988) describes integration in terms of self-perceived identity, 
feeling of belonging, reference group, self-perceived competence, feeling of mastery, favourable attitude to social relations and perceive acceptance. Adopting Gordon's (1964) seven dimensions of integration, Cox's (1991) describes employees' integration in a diverse workforce from the following dimensions: (1) modes by which two groups adapt to each other and resolve cultural differences, (2) profiles of organizational members (job status, hiring, job placement), (3) membership of informal networks by the minority groups, (4) level of prejudice and discrimination, (5) feeling of belonging, loyalty and commitment to the organization, (6) friction, tension and power struggles between groups. For the purpose of this paper, integration refers to a diverse employee's perception and feelings of fairness, belonging, respected, inclusion, and freedom, and ability and willingness to interact with all the members of the organization. This feeling and perception is hypothesized to affect employee attitudes (affective and moral commitment).

A number of studies indicate that high level of employee integration can lead to higher productivity (Fiedler, 1966; Mitchell, 1986; Walsh, et al. 1988; Triandis, et al. 1965), whereas lack of integration can result in negative outcomes. For example, Benkkoff (1996) found that perception of being treated with respect has a positive correlation with employee identification, desire to stay and exertion of extra effort. McNerney (1994a) attributes higher turnover of minorities and women to lack of integration. Similarly, Hess (1993) and Jones (1983) argue that employees who feel alienated by the organizational policies and practices and by members of the organization are less likely to be productive. Basically, high level of employee integration would lead to higher job satisfaction, which in turn would lead to affective and moral commitment. In fact, evidence indicates that the more satisfied employees are with their jobs, the more broadly they define their responsibilities, and the more so-called "organization citizenship behaviour" they define as in-role ( Morrison, 1994).

Proposition: Other things being equal, diverse employees who are integrated are more likely to have affective and moral commitment to their organization. And integration would enable diverse employees to acquire knowledge and skills and utilize them to benefit the organization.

\section{EMPLOYEE COMMITMENT}

Organizational commitment has been described from behavioural as well as attitudinal dimensions (Mottaz, 1989; Randall et al. 1990). However, the primary focus of this paper is on the latter. The relevance of organizational commitment in our framework is based on research which indicates that, less committed and alienated employees are more likely to have lower motivation and productivity and/or quit their job (Johnston, et al. 1990; Moch, 1980). And employee commitment has been found to relate to workforce diversity (Tsui, et al 1992). Two dimensions of attitudinal commitment are relevant to our framework. They are affective and moral commitment.

Jaros et al. (1993: 954) defines affective commitment as " the degree to which an individual is psychologically attached to an employing organization through feelings such as loyalty, affection, warmth, belonging, fondness, happiness, pleasure and so on". Setton, et al. (1996) demonstrated that affective commitment to organizations is based on workers "e perceptions of 
the support they receive from their organizations. And Sanchez and Brock (1996) found strong correlation between perceived discrimination and employees ${ }^{\text {ee }}$ job satisfaction, work tension and role conflict. These findings reinforced the proposition that how diverse employees feel or perceive they are treated would influence their commitment to the organization.

Drawing on the work of several authors, Jaros et al. (1993: 955) conceptualised moral commitment "as the degree to which an individual is psychologically attached to an employing organization through internalisation of its goals". Central to this definition is the idea of duty and obligation (Jaros et al. 1993). Evidence suggests that moral/normative commitment is strongly associated with "organizational citizenship behaviour" (Schwartz and Tessler, 1992). And Morrison (1994) found that the higher the level of moral and affective commitment experienced, the more broadly employees define their responsibilities, and the more so-called "organizational citizenship behaviour" they define as in-role.

Proposition: Diverse employees who have affective and moral commitment to their organization are more likely to engage in OCB than those who have no commitment.

\section{CONCLUSION}

Although research and theorising on organizational demography and interethnic interaction have being going on for decades, research on the strategic significance of diversity is only just beginning. In spite of the recent development however, the emphasis is still on how to manage diversity rather than on how to take advantage of diversity. The neglect of this dimension of diversity is responsible for the limited understanding and inadequate theoretical development in the field. Current knowledge of how diversity can improve organizational competitiveness and overall effectiveness is still limited. Although many experts in the field have being urging organizations to manage and take advantage of diversity, the relevant theories that will guide this endeavor are yet to be articulated. (See Powell, 1998 for a more recent theory on how organization can take advantage of diversity). In this paper we sought to contribute to the understanding of the topic by providing an analytical framework that explains factors that can influence a diverse employee's willingness and ability to engage in OCB. It is an indirect attempt to address the issue of why diversity would not always lead to desirable outcome to organizations.

Another aim of the paper is to provide testable propositions in order to frame future research directions in the study of how organizations can utilize their diverse workforce. The challenge for theorists and researchers is not only to test the propositions but also to integrate the topic of diversity into the mainstream human resource management (HRM) and organizational behavior (OB) literature.

On the basis of the framework advanced in this paper, we envisioned the development of HRM policies and practice that are anchored to the idea of integration and commitment. Significant attempts have been made by many organizations to follow this direction. However, such effort still lags behind what can be conceivably achieved. I believe social exchange theory as described in this paper holds the key to developing appropriate HRM policy and 
practice that can take advantage of diverse workforce. The theory can be used to elicit OCB from diverse employees. For example, developing the appropriate policy and practice will ensure that diverse employees reciprocate by OCB. Similarly, organizations can develop relevant policies and practices to target the dominant group in order to avoid backlash against diversity policies.

\section{References}

Adams, J. S (1963). Towards an understanding of inequity. Journal of Abnormal and Social Psychology, 67, 422-436

Adler, N J (1991). International Dimension of Organizational Behaviour. PSW KENT

Adler, N.J \& Izraeli, D.F, (1994). Competitive Frontiers: Women Managers in Global Economy. Cambridge, Massachusetts, Blackwell

Adler, P.S (1975). 'The Transactional Experience: An Alternative View of Culture Shock'. Journal of Humanistic Psychology, 15, 4: 13-23

Babiker, I; Cox, J and Miller, P (1980). The measurement of culture distance and its relationship to medical consultations, symptomatology and examinations performance of overseas students at Edinburgh University. Social Psychiatry, 15 pp. 109-116

Back, K (1959). Influence through social communication. Journal of Abnormal and Social Psychology, 46: pp. 9-23

Bamberger, P., Admati-Dur, M \& Harel, G (1995). Gender-based wage and promotion discrimination in Israeli High-Technology Firms: Do Unions make a difference? Academy of Management Journal, 38(6) 1744-1761

Bardo, J W and Bardo, D.J (1980). Dimensions of adjustment for American settlers in Melbourne, Australia. Multivariate experimental Clinical Research, 5, pp. 23-28

Baron, J N; Mittman, B S and Newman, A E (1991). Targets of opportunity: organizational and environmental determinants of integration within the California civil service 1979-1985. American Sociological Review, 55, 155-175

Beehr, T; King, L \& King, D (1990). Social support and occupational stress: Talking to supervisors. Journal of Occupational Behavior, 36: 61-81

Benkoff, B (1996). Disentangling organizational Commitment: The dangers of the OCQ for research and policy. Personnel Review, 26, 1\&2, 114-131

Bizman, A. and Amir, Y. (1982). Mutual Perceptions of Arabs and Jews in Israel. Journal of Cross-cultural Psychology, vol. 13 (4), sec. 1982, pp. 461 - 469.

Black, J S and Mendenhall, M (1990). Cross-cultural Training Effectiveness: A Review and a Theoretical Framework for Future Research, Academy of Management Review, 1990, vol. 15(1) pp. 113-136 


\section{Macrothink}

International Journal of Human Resource Studies

ISSN 2162-3058

2015, Vol. 5, No. 4

Black, J S, Mendenhall, M, and Oddou, G (1991). Toward a comprehensive model of International Adjustment: An Integration of Multiple Theoretical Perspective. The Academy of Management Review. vol. 16 (2) April, 1991. pp. 291-317

Blau, P.M (1964). Exchange and power in social life. New York: Wiley

Blau, P.M (1977). Inequality and hetrogeneity. New York: Free Press

Bobad, E and Wallbott, H (1986). The effects of social factors on emotional reactions. In K Sherer; H. Wallbott, and A. Summerfield (eds.) Experiencing emotions: A cross-cultural study. Cambridge: Cambridge University Press

Bochner, S. (1976). Religions Role Differentiation as an Aspect of Subjective Culture. Journal of Cross-cultural Psychology, 7, pp. 3 - 19.

Breakwell, G.M (1986). Coping with threatened identities, Metheun, New york.

Brewer, M B and Campbell, D T (1976). Ethnocentrism and intergroup attitudes. New York: John Wiley

Brein, M and David, K (1971). Intercultural communications and the adjustment of the sojourner. Psychological Bulletin, 1971, 76, pp. 215-230.

Brickson, S (2000). The impact of identity orientation on individual and organizational outcomes in demographically diverse settings. Academy of Management Review, 25(1), $82-101$

Brislin, R (1981). Cross-cultural encounters: Face-to-Face interaction. New York: Pergamon Press, 1981.

Brockner, J., Tyler, T.R., \& Cooper-Schneider, R. (1992). The influence of prior commitment to an institution on reactions to perceived unfairness: The higher they are, the harder they fall. Administrative Science Quarterly, 37, 241-261

Chatman, T.A \& Barsade, S.G (1995). Personality, organizational culture and cooperation: Evidence from business simulation. Administrative Science Quarterly, 40: 423-443

Collins, A \& Frankenhaeuser, M (1978). Stress responses in male and female engineering students, Journal of Human Stress, June, 43-48

Copeland, L (1988a). Learning to manage a multicultural workforce. Training, May 1988, pp. 48-56.

Copeland, L (1988b). Valuing workforce diversity. Personnel Administrator, November 1988;

Cox, T (1991). The multicultural organization. Academy of Management Executive, 1991 vol. 5(2) pp. 34-47

Cox, T (1993). Cultural diversity in organizations: Theory, research and practice. San Francisco: Barrett-Koehler 


\section{I Macrothink}

International Journal of Human Resource Studies ISSN 2162-3058 2015, Vol. 5, No. 4

Cox, T and Blake, S (1991). Managing cultural diversity: implications for organizational competitiveness. Academy of Management Executive, 1991 vol. 5(3), pp 45-56

Deckop, J; Mangel, R and Cirka, C (1999). Getting more than you pay for: Organizational Citizenship behavior and pay for performance plan. Academy of Management Journal. 42(4) 420-428

Detweiler, R (1975). On inferring the intensions of a person from another culture. Journal of Personality, 1975, 43, pp. 591-611

Detweiler, R (1978). Culture, Category-width, and Attribution: A model-building approach to the reasons for culture effects. Journal of Cross-Cultural Psychology, vol. 9 (3), pp. 259-284

Detweiler, R (1980). Intercultural Interaction and the categorisation process: A Conceptual Analysis and Behaviour Outcome. International Journal of Intercultural Relations, 4, pp. 275-93.

Dimaggio, P.J \& Powell, W.W (1983). The iron cage revisited: Institutional isomorphism and collective rationalityin organizational fields. American sociological Review, 48: 147-160

Dinges, N (1983). Intercultural competence. In Landis and R W Brislin (eds.), Handbook of intercultural training (vol. 1). New York: Pergamon Press

Dodd, C H (1982). Dynamics of Intercultural Communication. WmC Brown Company Publishers

Dutton, J.E., Dukerich, J.M., \& Harquail, C.V. (1994). Organizational images and member identification, Administrative Science Quarterly, 39, 239-263

Earley, P C (1993). East Meets West Meets Mideast: Further Explorations of Collectivistic and Individualistic Work Groups. Academy of Management Journal, 36, 1993, pp. 319-348

Eisenberger, R., Fasolo, P., \& Davis-LaMastro, V (1990). Perceived organizational support and employee diligence, commitment and innovation, Journal of Applied Psychology, 75: $51-59$

Eisenberger, R., Huntington, R.; Hutchinson, S \& Sowa, D (1986). Perceived organizational support, Journal of Applied Psychology, 71: 500-507

Elsass, P.M \& Graves, L.M (1997). Demographic diversity in decision-making groups: The experience of women and people of color. Academy of Management Review, 22(4) 946-973

Ely, R.J (1995). The power of demography: Women's social construction of gender identity at work. Academy of Management Journal, 38 (3) 589-634

Etzioni, A (1964). Modern organizations. Englewood Cliffs, NJ: Prentice -Hall

Fahr, J., Podsakoff, P.M., \& Organ, D.W. (1990). Accouinting for organizational citizenship behaviour: Leader fairness and task scopre versus satisfaction. Journal of Management, 16: $705-722$ 


\section{I Macrothink}

International Journal of Human Resource Studies ISSN 2162-3058 2015, Vol. 5, No. 4

Feldman, D C and Holly, B T (1993). Expatriate repatriation and domestic geographical location: An empirical investigation of adjustments. Journal of International Business Studies, vol. 24(3) pp. 507-528

Fernandez, J P (1981). Racism and sexism in corporate life. Lexington MA: Lexington Books Fernandez, J.P (1991). Managing a diverse workforce. Lexington. MA Lexington Books

Fiedler, F E (1966). The effect of leadership and cultural heterogeneity on group performance: A test of the contingency model. Journal of Experimental Social Psychology, 2, 237-264

Fitzsimmons, D S and Eyring, A R (1993). Valuing and managing cultural diversity in the Workplace. American Journal of Hospital Pharmacists, vol. 50, Nov. 1993, pp. 2404-2407

Furnham, A and Bochner, S (1986). Culture shock: Psychological reaction to unfamiliar environment. Routledge

George, J; Reed, T; Ballard, K; Colin, J \& Fielding, J (1993). Contact with AIDS patients as a source of work-related distress: Effects of organisational and social support. Academy of Management Journal, 36: 157-171

Gertsen, M C (1990). Intercultural Competence and Expatriates. The International Journal of Human Resource Management. vol. 1 (3) Dec. 1990, pp. 341-362.

Goodmans, P.S (1974). An examination of referents used in the evaluation of pay. Organizational Behavior and Human Performance, 12, 170-195

Gordon, M (1964). Assimilation in American life. Oxford Press: New York

Greenberg, J; Pyszczynski, T; and Solomon, S (1986). The causes and consequences of need for self-esteem: A terror management theory. In R F Baumeister (Ed), Public self and private self: pp. 189-212. New York: Springer-Verlag

Greenhaus, J.H., Parasuram, S., \& Wormley, W.W (1990). Effects of race on organizational experience, job performance evaluation, and career outcomes. Academy of Management Journal, 33: 64-86

Gudykunst, W B (1985). The influence of cultural similarity, type of relationships, and self-monitoring on uncertainty reduction processes. Communication Monographs, 52, pp. 203-217

Gudykunst, W B and Hammer, M R (1984). Dimensions of Intercultural Effectiveness: Culture specific of culture general. International Journal of Intercultural Relations, 8, pp. 1-10

Gudykunst, W B and Kim, Y Y (1984). Communicating with Strangers. An Approach to Intercultural Communication. Random House, New York

Gullahorn, J and Gullahorn, J (1963). An extension of U curve hypothesis. Journal of Social Issues, 19, pp. 33-47 


\section{Macrothink}

International Journal of Human Resource Studies

ISSN 2162-3058 2015, Vol. 5, No. 4

Gwartney-Gibbs, P A and Lach, D H (1994). Gender differences in clerical workers disputes over tasks, interpersonal treatment and emotion. Human Relations, vol. 47(6), pp. 611-639

Hammer, M R (1987). Behavioural dimensions of intercultural effectives: A replication and extension. International Journal of Intercultural Relations, vol 11, pp. 65-88, 1987.

Hammer, M R; Gudykunst, W B, and Wiseman, R L (1978). Dimensions of Intercultural effectiveness: An exploratory study. International Journal of Intercultural Relations vol. 2 pp. 282-393

Harris, A (1994). Breaking the glass ceiling for senior executives. Human Resource Focus, March, pp. 1-5

Hawes, F and Kealey, D J (1981). An empirical study of Canadian technical assistance. International Journal of Intercultural Relations, vol. 5 pp. 239-258, 1981

Hays, R D (1971). Ascribed behavioural determinants of success-failure among U.S expatriates Managers. Journal of International Business Studies, 2, pp. 40-46

Heery, W (1994). Corporate mentoring can break the glass ceiling. Human Resource Focus, May, pp. 17-18

Heilman, M..E (1983). Sex bias in work-settings: the lack of fit model. In L.L Cummings \& B.M. Staw (eds.). Research in organizational Behavior, vol. 5: 269-298. Greenwich, CT: JAI Press

Hess, J A (1993). Assimilating newcomers into organization: A cultural perspective. Journal of Applied Communication Research, May, pp. 189-210

Hicks-Clarke, \& Iles, P (2000), Climate for diversity and its effects on career and organisational attitudes and perceptions. Personnel Review. 29(3) 324-345

Hirschman, A (1970). Exit, voice and loyalty: Responses to decline in firms, organizations and states, Cambridge, MA, Harvard University Press

Holmes, J.G (1981). The exchange process in close relationships: Microbahviour and Macromotives. In M.J Lerner and S.C Lerner (eds.). The justice motive in social behaviour: 261-284. New York: Plenum

Homans, G C (1974). 'Social behavior: Its elementary forms'. Revised edition, New York: Harcourt Brace, 1974

Horgan, D D (1989). A cognitive learning perspective on women becoming expert managers. Journal of Business Psychology, 3: pp. 299-313

Huselid, M.A (1995). The impact of human resource management practices on turnover, productivity, and corporate financial performance. Academy of Management Journal. 38(3) 635-672 


\section{Macrothink}

International Journal of Human Resource Studies ISSN 2162-3058 2015, Vol. 5, No. 4

Ibarra, H (1995). Race opportunity and diversity of social circles in managerial networks. Academy of Management Journal, 38 (3), 673-703

Jackson, B W; LaFasto, F; Schultz, H G; and Kelley, D (1992). Diversity. Human Resource Management, Spring/Summer, 1992, vol. 31 (1 \& 2). pp. 21-34

Jacques, E (1961). Equitable payment. London: Heinemann

James, K; Lovato, C; and Khoo, G (1994). Social Identity correlates of minority workers' health. Academy of Management Journal, vol. 37(2) pp. 382-396

Jaros, S J; Jermier, J M; Koehler, J W; and Sincich, T (1993). Effects of continuance, Affective, and Moral Commitment on the withdrawal process: An Evaluation of Eight structural equation models. Academy of Management Journal, 36(5) October, 1993, pp. 951-995

Jenner, L (1994). Diversity Management: What does it mean?. Human Resource Focus. January, pp. 9

Jones, G R (1983). Psychological Orientation and the process of organizational socialization: An interactionist perspective. Academy of Management Review, 8 pp. 464-474

Jones, G.R \& Wright, P.M (1992). An economic approach to conceptualising the utility of human resource management practices. In K. Rowland \& G.Ferris (Eds.), Research in personnel and human resource management, vol. 10: 271-299. Greenwich, CT: JAI Press

Jonston, M W; Parasuraman, A; Futrell, C M and Black, W C (1990). A longitudinal assessment of the impact of selected organizational influences on sales people's organizational commitment during early employment. Journal of Marketing Research, 27 (August), pp. 333-344

Kahn, W.A (1990). Psychological conditions of personal engagement and disengagement at work, Academy of Management Journal, 33, 692-724

Kanter, R (1977). Men and Women of the corporation. New York: Random House.

Kanter, R (1990). Token women in the corporation. In J. Heeren and M. Mason (eds), Sociology: Windows on Society. Roxbury: Los Angeles

Kasscau, P L (1977). Age and race discrimination reported by middle age and older persons. Social Forces, 55, pp. 728-742

Katz, D (1964). The motivational basis of organizational behavior. Behavioural Science, 9: $131-133$

Katz, I and Hass, R G (1988). Racial ambivalence and American value conflict: Correlational and primary studies of dual cognitive structure. Journal of Personality and Social Psychology, 55: pp. 893-905

Kim, Y Y (1977). Communication patterns of foreign immigrants in the process of acculturation. Human Communication Research, 1977, 4, pp. 66-77 


\section{I Macrothink}

International Journal of Human Resource Studies

ISSN 2162-3058

2015, Vol. 5, No. 4

Kirmeyer, S.L \& Dougherty, T (1988). Work load, tension and coping: Moderating effects of supervisor support. Personnel Psychology, 125-139

Kleiner, M.M (1990). The role of industrial relations in firm performance. In J.A. Fossum \& J. Mattson (Eds.), Employee and labor relations. 4.23-4.43. Washington, DC: BNA Press

Klineberg, O (1981). The role of international university exchanges. In S. Bochner (eds). The mediating person: Bridges between cultures. Boston, Schenman.

Konovsky, M.A, \& Pugh, S.D (1994). Citizenship behaviour and social exchange. Academy of Management Journal, 37(3), 656-669

Konrad, A.M and Linnehan, F (1995). Formalised Human Resource Management structures: Coordinating equal employment opportunity or concealing organizational practices. Academy of Management Journal, 38(3) 787-820

Lott, A J and Lott, B E (1961). Group cohesiveness, communication level, and conformity. Journal of Abnormal and Social Psychology, 62: pp. 408-412

Marjoribanks, K. and Jordan, D.F. (1986). Stereotyping among Aboriginal and Anglo-Australians: The Uniformity, Intensity, Direction, and Quality of Auto and Hetero Stereotypes. Journal of Cross-Cultural Psychology, vol. 17 (1) pp. 17 -28.

Markus, H.R \& Kitayama, S (1991). Culture and Self: Implications for cognition, emotion and motivation. Psychological Review, 98: 224-253

Markus, H.R \& Wurf, E. (1987). The dynamics of self-concept: A sociopsychological perspectives, In. M.R. Rosenzweig and L.W. Porter (Eds.), Annual Review of Psychology, $38,299-337$

Marsden, P.V (1988). Homogeneity in confiding relations. Social Networks, 10: 57-76

Maruyama, M (1994). Mindscapes in Management: Use of individual differences in multicultural management. Aldershot, England: Darmouth Publishing

Mayer, J C (1984). Towards an explanation of ethnocentrism versus ethnorelativism based upon reference group orientation. In G.K Verma and C Bagley (eds.). Race Relations and Cultural Differences. Croom Helm, London

Mayer, R and Schoorman, F (1992). Predicting participation and production outcomes through a two-dimensional model of organizational commitment. Academy of management Journal, 35: 671-684

McNerney, D (1994a). The bottom-line value of diversity. Human Resource Focus, May, pp. $22-24$

McNerney, D (1994b). Competitive advantage: Diverse customers and stakeholders. Human Resource Focus, June, pp. 9-10 


\section{Macrothink}

International Journal of Human Resource Studies ISSN 2162-3058 2015, Vol. 5, No. 4

Mendenhall, M and Oddou, G (1986). Acculturation Profiles of Expatriates Managers: Implications for Cross-Cultural Training Programs. Columbia Journal of World Business, Winter, 1986, pp. 73-79

Mendoza, R.H (1989). An empirical scale to measure type and degree of acculturation in Mexican-American adolescents and adults. Journal of Cross-cultural Psychology, 20: $372-385$

Meyer, J.P., Paunonen, S.V., Gellatly, I.R., Goffin, R.D., \& Jackson, D.N (1989). Organizational commitment and job performance: It's the nature of commitment that counts. Journal of Applied Psychology, 74, 152-156

J.W \& Rowan, B (1977). Institutional organizations: Formal structure as myth and ceremony. American Journal of Sociology, 83: 340-363

Mitchell, R (1986). Team building by disclosure of internal frames of reference. Journal of Applied Behavioural Science, 22(1) pp. 15-28

Moch, M K (1980). Job involvement, internal motivation and employees' integration into networks of work relationships. Organizational Behaviour and Human Performance, 25 pp. $15-31$

Moorman, R.H. (1991). The relationship between organizational justice and organizational citizenship behaviours: Do fairness perception influence employee citizenship? Journal of Applied Psychology, 76: 845-855

Moorman, R.H, Blakely, G.L \& Niehoff, B.P (1998). Does perceived organizational support mediate the relationship between procedural justice and organizational citizenship Behavior? Academy of Management Journal, 41(3), 351-368

Morrison, A.M and Von Glinow, M.V (1990). Women and Minorities in management. American Psychologist, 45: 200-208

Morrison, E W (1994). Role definition and Organizational Citizenship Behaviour: The importance of the employee perspective. Academy of Management Journal, 37(6), pp. $1543-1567$

Morrison, E.W and Phelps, C.C (1999). Taking charge at work: Extra-role efforts to initiate workplace change. Academy of Management Journal, 42(4(403-419

Morrison, A M; White, R P; and Van Velsor, E (1987). Breaking the glass ceiling: Can women reach the top of America's largest corporations?. Chicago: Addison-Wesley.

Mottaz, C (1989). An analysis of the relationship between attitudinal commitment and behavioral commitment, Sociological Quarterly, 30: 143-158

Niehoff, B.P and Moorman, R..H (1993). Justice as a mediator of the relationship between methods of monitoring and organizational citizenship behaviour. Academy of Management Journal, 36(3), 527-556 
Oddou, G and Mendenhall, M (1984). Person Perception in Cross-Cultural Setting: A Review of Cross-cultural and Related Cognitive Literature, International Journal of Intercultural Relations, vol. 8, pp. 77-96 and turnover, Administrative Science Quarterly, 34: 21-37

Organ, D W (1988). Organizational citizenship behaviour: The good soldier syndrome. Lexington, MA: Lexington Books.

Organ, D.W (1990). The motivational basis of organizational citizenship behavior. In B.M Staw and L.L Cummings (Eds.), Research in organizational Behavior. Vol. 12: 43-72. Greenwich, CT: JAI Press

Perry, E.L; Davis-Blake, A \& Kulik, C T (1994). Explaining gender-based selection decisions: A Synthesis of contextual and cognitive approaches. Academy of management Review. 19(4) 786-820

Pettigrew, T F and Martin, J (1987). Shaping the organizational context for Black American inclusion. Journal of Social Issues. vol. 43(1), 1987, pp. 41-78

Pfeffer, J (1983). Organizational Demography. In L L Cummings and B M Staw (eds.). Research in Organizational Behaviour, Vol. 5 pp. 299-357. Greenwich. CT: JAI Press

Pfeffer, J \& Davis-Blake, A (1987). Understading organizational wage structures: A resource dependance approach. Academy of management journal, 30: 437-455

Pfeffer, J \& Salancik, G.R (1978). The external control of organizations: A resource dependence perspective. New York: Harper \& row

Powell, G (1998). Reinforcing and extending today's organizations: The simultaneous pursuit of person-organization fit and diversity. Organizational Dynamics, 26(3) 50-61

Randall, D M; Fedor, D B; and Longnecker, C O (1990). The behavioural expression of organizational commitment. Journal of Vocational Behaviour, 36: 210-224

Richard, O. C (2000). Racial diversity, business strategy, and firm performance: A resource-based view, Academy of Management Journal, 43(2) 164-177

Ridgeway, C.L (1988). Gender differences in task groups: A status and legitimacy account. In M. Webster \& M. Foschi (Eds.), Status generalization: A new theory and research; 188-206, Stanford, CA: Stanford University Press

Rousseau, D.M (1989). Psychological and implied contracts in organizations. Employee Responsibilities and Rights Journal, 2: 121-139

Rousseau, D.M., \& McLean Parks, J (1993). The contracts of individuals and organizations. In L.L. Cummings \& B.M. Staw (Eds.), Research in organizational behavior. Vol. 15: 1-47. Greenwich, CT: JAI Press.

Ruben, B D (1976). Assessing communication competency for intercultural adaptation. Group and Organizational Studies. 1: pp. 334-354. 


\section{Al Macrothink}

International Journal of Human Resource Studies ISSN 2162-3058 2015, Vol. 5, No. 4

Sanchez, J and Brock, P (1996). Outcomes of perceived discrimination among Hispanic employees: Is diversity management a luxury or a necessity? Academy of Management Journal, 39(3), 704-719

Sanchez, J. \& Fernendez, D (1993). Acculturative stress among Hispanics: A bidimensional model of ethnic identification. Journal of Applied Social Psychology, 23: 654-668

Schenkler, B.R, (1985). Self-identification: Towards an integration of the private and public self,. In R. Baumiester (Ed.), Public self and private self, Springer-Verlag, New York

Scwartz, S. H and Tessler, R.C (1992). A test of a model for reducing measured attitude-behaviour discrepancies. Journal of Applied Psychology, 68 pp. 653-663

Segall, M H; Dasen, P R; Berry, J W; Poortinga, Y H (1990). Human Behaviour in Global Perspective. Pergamon Press, New York, Oxford, Sydney, 1990.

Singer, M R (1987). Intercultural Communication: A Perceptual Approach. Prentice-Hall, Inc. Engelwood Cliffs, New Jersey

Singh, R (1998). Redefining psychological contract with the US workforce: A critical task for strategic human resource management planners in the 1990s. Human Resource Management, 37(1) 61-69

Smith, B (1994). Recruitment insights for strategic workforce diversity. Human Resource Focus January 1994

Steele, C (1988). The psychology of self-affirmation: Sustaining the integrity of the self, In L. Berkowitz (ed.) Advances in experimental social psychology, 261-302, New York: Academy Press

Stephenson, K and Krebs, V (1993). A more accurate way to measure diversity. Personnel Journal, October, 1993, pp. 66-74

Stone, D.L \& Colella, A (1996). A model of factors affecting the treatment of disabled individuals in organizations. Academy of Management Review, 21(2), 352-401

Stryker, S \& Serpe, R.T (1982). Commitment, identity salience and role behaviour: theory and Research example. In W. Ickers and E. Knowles (Eds.), Personality roles and social behaviour, springer-Verlag, New York; 199-219

Summer, W.G. (1906). Folkways. Boston: Ginn.

Tajfel, H. (1969). Cognitive Aspects of Prejudice. Journal of Social Issues, 25, pp. 79-97.

Taft, D (1988). The psychological adaptation of Soviet immigrants in Australia. In Y Y Kim and W.B Gudykunst (eds), Cross-cultural Adaptation: Current Approach. Sage Publication, Newbury Park

Thomas, D.A (1990). The impact of race on manager's experience of developmental relationships: An intra-organizational study. Journal of Organizational behavior, 2: 479-492 


\section{Macrothink}

International Journal of Human Resource Studies ISSN 2162-3058 2015, Vol. 5, No. 4

Thomas, D A (1993). Racial Dynamics in Cross-race Developmental Relationships. Administrative Science Quarterly, 38 (1993): pp. 169-194

Thomas, D.A \& Alderfer, C.P (1989). The influence of race on career dynamics: Theory and research on minority career experiences. In M.B. Arthur; D.T. Hall \& B.S. Lawrence (Eds.), Handbook of career theory. 133-158. Cambridge: Cambridge University Press

Thomas, R R (1990). From Affirmative action to Affirmative Diversity. Harvard Business Review, 2, March/Arpil 1990, 107-117

Torbiorn, I (1982). Living abroad: Personal adjustment and personnel policy in the overseas setting. New York: Wiley, 1982

Triandis, H (1976). Interpersonal Behaviour. Monterey, Calif.: Brooks/Cole, 1976.

Triandis, H (1977). Subjective culture and interpersonal relations across cultures. Loeb-Adler, L (ed.) Issues in Cross-cultural Research. Annals of the New York Academy of Sciences, 285, pp. $418-434$

Triandis, H C; Hall, E T and Ewan, R (1965). Member heterogeneity and dyadic creativity. Human Relations, 18, 33-55

Triandis, H C; Kurowski, A T; and Chan, D K S (1993). Extracting the Emics of Diversity. International Journal of Intercultural Relations, vol. 17 pp. 217-234

Tsui, A.S \& O'Reilly, C.A (1989). Beyond simple demographic effects: The importance o relational demography in supervisor subordinate dyads. Academy of Management Journal, 32: $402-423$

Tsui, A.S; Egan, T; and O'Reilly, C A (1992). Being Different: Relational Demography and Organizational Attachment. Administrative Science Quarterly, 37, 1992, pp. 549-579

Tsui, A.S and O'Reilly, C A (1994). Beyond simple demographic effects: The importance of relational demography in superior-subordinates dyads. Academy of Management Journal, 32, pp. $402-423$

Tsui, A.S; Pearce, J.L; Porter, L.W \& Tripoli, A.M (1997). An alternative approaches to employee-organization relationships: Does investment in employees pay off. Academy of Management Journal. 40(5)

Tung, R L (1981). Selection and training of personnel for overseas assignments. Columbia Journal of World Business, 16(1), pp. 66-78

Tung, R L (1993). Managing Cross-National and Intra-National Diversity. Human Resource Management, Winter 1993, vol. 32(4), pp. 461-477

Van Dyne, L; Graham, J and Dienesch, R. (1994). Organisational Citizenship Behaviour: Construct redefinition, measurement, and validation. Academy of Management Journal. 37(4) $765-802$

Van Dyne, L \& Ang, S (1998). Organizational Citizenship Behaviour of contingent workers 


\section{Macrothink \\ International Journal of Human Resource Studies \\ ISSN 2162-3058 2015, Vol. 5, No. 4}

in Singapore, Academy of Management Journal, 41(6), 692-703

Van Velsor, E and Hughes, M W (1990). Gender differences in the development of managers: How women managers learn from experience. Technical report no. 145. Center for creative leadership, Greenboro. NC

Walsh, J P; Henderson, C M and Deighton, J (1988). Negotiated belief structures and decision performance: An empirical investigation. Organizational Behaviour and Human Decision Process, 42, pp. 194-216

Wayne, S.J; Shore, L.M., \& Linden, R.C (1997). Perceived organizational support and leader-member exchange: A social exchange perspectives, Academy of Management Journal, 40: $82-111$

Westin, A F and Felieu, A G (1988). Resolving employment disputes without litigation. Washington DC, Bureau of National Affairs

Wharton, A.S (1992). The social construction of gender and race in organizations: A social identity and group mobilisation perspectives. In P.T. Tolbert \& S.B. Bacharach (Eds.), Research in Solciology of organizations, vol. 10:55-84; Greenwich, CT: JAI Press

Wiersema, M F and Bird, A (1993). Organizational Demography in Japanese Firms: Group Heterogeneity, Individual Dissimilarity, and Top Management Team Turnover, Academy of Management Journal, vol. 36, 5, pp. 996-1025

Wiseman, R L; Hammer, M R and Nishida, H (1989). Predictors of Intercultural Communication Competence. International Journal of Intercultural Relations, vol 13, pp. 349370 .

Wood, W (1987). Meta analytical review of sex differences In-Group performance. Psychological Bulletin, 102, 53-71 